\title{
TEACHING WRITING SKILL THROUGH CONCEPTUAL NETWORK ON THE NINTH GRADE STUDENTS OF SMP NEGERI 3 KUTA SELATAN IN THE ACADEMIC YEAR 2009-2010
}

\author{
Ketut Wardana and I Nengah Astawa \\ English Education Department, Faculty of Education and Teacher Training, \\ University of Mahasaraswati Denpasar
}

\begin{abstract}
This study is aimed to improve the studens's writing ability during the teaching learning process. The Conceptual Network activities had been assumed to be able to improve the student's ability in writing. Since the technique had been applied the students could increase their achievement both in terms of score and ability in writing aspects such as grammar, punctuation, spelling and vocabularies. The subjects of the present study was IX I of SMP Negeri 3 Kuta Selatan in academic year 2008-2009.The total of the subjects under study was 42 students which consists of 20 females and 22 males. The present study made use of a classroom action research design. There were two cycles applied and each of which covered three session and involved four steps namely planning, action, observation, and reflection. There were three instruments used in this study; test, questionnaires, and observation sheet. This study was carried out based on the results of pre-test which revealed that students' writing ability was unsatisfying. From the writing assessment scale used, it was proved that achievement of pre-test of subject under study was only 4.83 which were considered very low. The finding showed that there were continuous improvements on the students mean score after being given treatment in two cycles. In cycle I, the score of reflection 1 was 5.47 in reflection 2, the score was 6.09, the score in reflection 3 was 6.83.It was calculated that the grand mean score of cycle I was6.13. and it proved that student's writing ability was considered fairly satisfactory by using Conceptual Network strategy. Next, three reflections were applied in cycle II to anticipate unsatisfied reaction from the researcher. It showed that the score in reflection 4 was 7.47, reflection 5 was 8.21 and reflection 6 reached up to 8.76. The grand mean of cycle II was 8.14 which meant the student's writing ability were considered much better according to the rate description. The difference between grand mean cycle I and cycle II was 2 points. The result of questionnaire showed that item A was $59.25 \%$ which meant they liked writing with Conceptual Network strategy very much, Item B was $32.43 \%$ they liked it, and item $C$ was $8.31 \%$, that means they were not sure and none of them chose D or 0 . From the result of the study, this indicated that Conceptual Network strategy could help the students of SMP Negeri 3 Kuta Selatan improve their writing ability.
\end{abstract}

Key Words: teaching, Conceptual Network, writing, improvement 


\section{INTRODUCTION}

Two concentrations in language learning are language elements and language skills. Both terms are closely interrelated. Language elements consist of grammar, vocabulary and phonology and language skills describes about listening, speaking, reading and writing. One of the productive skills which needs special and complex skills is writing. The mastery of writing ability will enable the students to communicate their ideas.

Consciously or unconsciously, the importance of writing skill is highly required for our lives, as students, citizens, friends, and consumers. In our highly literate society, there are literary hundreds of different types of written text, much more a variety than found in spoken texts. We use writing skills in reports, letters, recommendation, application, and numerous other written documents every day. As students, they have to write class notes, summaries, of texts, books chapters, and conclusion about an experiment in science lab, brief essays and many more. Shortly, writing well is also one of the most useful crafts in which the students develop essential prospective jobs Ackley, (1986:135).

On the contrary of the importance of writing described above, many students of SMP Negeri 3 Kuta Selatan consider that writing is the most difficult language skill. The reason may vary from limitation of vocabularies, lack of linguistic competence, that include all the elements of writing such as grammar, style, diction, punctuation, vocabulary, and spelling. The students rarely have completely vague ideas of where they are heading to. When they start, they may hit dead end, change direction, or tear everything up and throw them to waste bin.

Concerning more difficulties about the written ideas explained above, students are facing complex problems in improving their writing skill. Some are not able to write even one correct simple sentence that represents full meaning while others can not compose compound and complex sentences found in paragraphs, which make them frustrated. From this point of view the researcher observed that the students need to develop their writing skill by describing meaning of word with its basic features that a new strategy, that is the researcher's opinion, called a conceptual network can help. Let say the word 'dog', the students should be able to write what features that it has, such as its name, its color, its habits and so on. The students can make a short paragraph from this strategy by developing from its basic features. 
Considering to the problems encountered by students and the description of related strategy explained above, the researcher decided to apply the technique to improve students' writing skill through Conceptual Network Strategy. Systematically this study was held by giving the students opportunities to describe whatever they like to. Conceptual Network strategy can be a challenging classroom writing technique to improve students' writing ability. It was applied in SMP Negeri 3 Kuta Selatan especially ninth grade students in academic year 2009-2010 due to the assumption of their weaknesses in writing skill.

\section{The Research Problem}

On the line of the whole aspects of the study being investigated, students should be encouraged to improve their writing skill as basic ability to achieve communicative competence through written ideas. Due to its complexity and relation to the improvement of skill in teaching learning process, the researcher decided to apply classroom action research that involved the students under study. So the research question can be concisely formulated" to what extents can the writing skill of ninth grade students of SMP Negeri 3 Kuta Selatan be improved through Conceptual Network strategy?”

\section{Objective of the study}

The description of the difficulties in writing as explained above makes the researcher focus on. The objective of the present study is intended to improve the students' writing ability through Conceptual Network Strategy which was carried out on the ninth grade students of SMP Negeri 3 Kuta Selatan

\section{Significance of the study}

After observing the study on the students under investigation, the result is hoped tobe useful in giving the readers clear insight on implication of the strategy. The result magnifies students' deeply imprinted comprehension that automatically increases their motivation. The result of the study under investigation would bring significant benefits to the teacher in enriching the existing writing techniques. The comparison of the applied strategy can avoid boredom using the same technique for different language skill. For the students related to the importance of writing skill in students' daily writing assignment, the result of the implication of the study through self correction is absolutely meaningful in understanding linguistic competence better. Furthermore the researcher had an opportunity in searching and applying the strategy to improve students writing skill that brings the writer up to high satisfaction. His involvement to the condition and situation of teaching learning process gives new 
experience in gathering deeper his human resource. General significance of the study for the institution in which the result can help the education institution increase the numerous existed collections of catalogue and subject kept in library as one of sources to improve English language skill

\section{Underlying Theories}

Every scientific investigation should be mainly conducted on basic of theoretical background and empirical evidences to defend and support the argumentation about the study being observed. The present investigation is based on the following theoretical frame work which will be completely discussed below that includes (1) conception of writing, (2) types of writing, (3) the reason of teaching, (4) essential component in writing, (5) Conceptual Network, and (6) the assessment of writing.

\section{Conception of writing}

Descriptively, writing has so broad meaning to gain precise definition based on its natural process. Every single definition may derive from different expert's points of views to another's; however, the meaning of writing always relates to transformation of ideas, attitude or massages through printed codes to the readers. There are many ways the messages are expressed according to period of time. For instance, along the journey of civilization, simple old writing can be seen from symbolic signs that represent hidden ideas which known and admitted by groups of people. This sort of writing usually found on the rough surface of caves, stones or bronze according to its technology at that time. Even though time goes by, and human can find modern writing using different kind of language and sophisticated media yet people still wonder how define this coded text. The ideas of writing definition may vary from one expert to another depending on what points of views and purposes they aim.

First definition comes from Hirsch in Hughey et al (1983:27); they state that writing is a way of recording languages by means of visible marks. Of course, it does not mean all writing has complete meaning. If it is only one or two words the readers may wonder what words come next because two words do not represent full meaning, because the meaning comes from the basic sequences of grammatical and lexical features from very simple phrases into a complicated discourse and polished by punctuation and styles as pronunciation, sound, and stress in spoken language.

\section{Types of writing skill}

Despite the fact about its complicated process, writing can take any forms to express ideas through meaningful sequences of sentences which are concluded as a paragraph. In 
classroom writing technique, developing one of the most appropriate types of writing skill must be adjusted accordingly depending on level of student's difficulties and writing proficiency. The following types of writing include paragraph writing, guided writing, and free writing will be concisely described below.

\section{Paragraph writing}

Paragraph writing can be concisely defined as groups of sentences that develop one main idea that are composed from unity, coherent, and well organized sentences. Unity of paragraph means that all supporting sentences in each paragraph can help writers develop the main idea. Furthermore a paragraph is called coherent if the words or phrases used within a paragraph connect one sentence with another. Finally a clear organization within each paragraph makes each sentence follow logically upon the preceding sentences. Form this points of view, Oshima and Hogue (1980: 55) underline a paragraph as basic unit of organization in writing that usually develop main ideas through topic sentences which point the statement of main idea of a paragraph and it is used to guide the direction of other sentences to follow. Each paragraph is separated unit marked by identifying the first word from the left margin or by leaving extra space above and below the paragraph.

The topic sentence should make the main idea of a paragraph immediately clear to readers and help the readers in following the supporting sentences easily.1) Supporting sentence that consists of major supporting sentence and minor supporting sentence make up the rest of paragraph..2) Concluding sentence is sentences that end and complete a paragraph. Coherence means that the parts of the paragraph are clearly and logically connected to one another. A coherent paragraph concerns with the way each individual sentence is linked or connected to the sentences before and after it, finally according to Baker (1988: 89) order is arrangement of information in a paragraph. The writer controls the presentation of which information is put first a paragraph.

\section{Guided writing}

The second type of writing which is used in classroom writing technique is called guided writing. This type of writing is provided for early stages of student learning how to write a composition. According to Raimes (1983: 85) guided writing is all the writing the students do for which a great deal of the content and form supplied. The students' writing is guided or controlled by various means, such as provision of questions to be answered, sentences to complete word or pictures to follow and any other ways in which the copying of single word as clue and student's writing is improved from guessing through context based 
on their understanding of linguistic competence such as grammar and vocabulary. The application of guided writing for early stages of students who just start the journey of written idea is appropriate because advantages of guided writing as Allen Campbell ( 1972:20) explains that guided writing gives the students a sense of progress and improvement which build confidence in their own ability. This is supported by Byrne (1979:84) that the composing of writing beyond sentence must be guided or controlled because it will keep learners who are weak in expressing themselves in writing and help the teacher to correct the learner's work easily.

\section{Free writing}

This type of writing is the opposite of guided writing in which the students' writing is not strictly guided and controlled so the written communication just flows down freely and spontaneously and this production can take any forms of work such as essay question or writing about particular topics. The linguistic competence is still concerned to convey meaning. It means that the free writing presents the learners' attempt to generate, organize, and express their ideas with their own sentences. Halm (1986: 75) describes that the characteristic of free composition may involve the students to invent and create sentences, paragraphs, and pages by themselves.Related to the appropriateness of this free writing should be not applied in the early stages of students, due to their limited comprehension of linguistic competence.

\section{The reason of teaching writing}

Requirement of written message is essentially acquired by students of any age in achieving the language target. So the purpose of writing is the achievement of ability in expressing ideas, conveying messages to the readers: the necessity should be seen as the most promising language skill even though some aspects of writing such as accuracy, clarity, and intensity seems very complicated for the students. Harmer (1998: 79) states that the reason and the purpose of teaching writing to the students include reinforcement, language development, learning style, and the most prospective reason; writing as skill. These terms are concisely described below.

\section{a) Reinforcement}

The application of simple writing is kind of gradually repetitious achievement of skillful assignment that can broaden their vocabularies and other language components needed in writing skill. The visual demonstration of language construction is valuable for 
both understanding of how it all fits together, and an aid to commit the new language memory.

\section{b) Language development.}

Teaching writing may help the students to develop the existing knowledge into written ideas. By writing, the students are able to develop their understanding about the usage of punctuation, spelling, or diction more accurately. Through writing, the student can strengthen their linguistic competence. The mental activity of students has to go through, which become ongoing learning experience.

\section{c) Language style}

Teaching the usage of style in writing can encourage the students to dig more hidden word or grammatical features. The consideration of subject, reader audience, and the purpose of writing requires various styles depending on formal or informal writing. For instance, choosing an appropriate style must go on with reader audience those who are supposed to read the writing : children, educated people, young or old people; therefore the style then must be adjusted to fix their interest. That is in writing, diction may provide many words for one single meaning, whether the students use car, mobile or ride. Commonly, it is completely admitted that writing is expressed in formal language in consideration of being educated.

\section{Writing as skill}

The most important reason for teaching writing, of course, it is a basic language skill, just as important as speaking, listening, and reading. The students need to know how to write simple announcement about oncoming holiday or invitation for party, how to write letters to new friends, how to put written reports, how to reply advertisement, and increasingly, how to write the use of electronic media.

\section{Essential component of writing}

As we realize that the complexity of writing can be seen from some factors; psychological, cognitive and linguistic factors. Psychological factor means that writing is a solitary act without audience and from the linguistic factors writing must be constructed more carefully concisely and coherently to ensure the meaning is clear. Linguistic factor concerns about writing in formal instructional rather than through natural acquisition process. The purpose of writing in general is the expression of ideas, the conveyance of message to the readers that consist language of component that involved in writing skill, such as :( a) vocabulary and diction (b) sentence structure,(c) sentence writing described below. 


\section{Conceptual Network Strategy}

Conceptual network is a term of describing lexicons trough three categories such as Super ordinate level, basic level and subordinate level, each of which describes different features of a lexeme or word. Let say the word ' a canary', the sub ordinate or specific features of the bird the students can write is that 1)-sings, 2)- is yellow 3)- is small.

\section{Assessment of writing skill}

To know the improvement of students' writing skill, as stated by Heaton (1975:5) that assessment of writing should be administered by applying a series of objective test. The test may be primarily constructed to reinforce students' skill and motivate the student's performance in a target language. According to Heaton (1975:159) criteria of evaluating writing must consist of validity and reliability. Validity of a test is the extent to which it measures what it is supposed to measure and nothing else. There are four types of validity; face validity, content validity, construct validity, and empirical validity.

\section{Subjects of the study}

The finding of any classroom action research can not be generalized to other groups of students even though they might be at the same school. Subject of the present study was concentrated on the tenth grade students of SMP Negeri 3 Kuta Selatan which consisted of 240 students, but the chosen subject is focused on grade IX 1 which has 42 students, 20 females and 22 males. The researcher determines this class as subject of the study because the students' ability in writing still needs improving.

\section{RESEARCH DESIGN}

Research is briefly defined as a process which involves defining a problem, stating an objective and formulating any hypothesis. This quotation which is taken from Nunan (1992: 75) has given the researcher clear insight about the sequences of steps in this investigation. That is, this study is consistently designed by using Classroom Action Research (CAR) due to its purpose to improve the student's skill through a certain strategy called Conceptual Network strategy. This study consists of two major cycles. Each cycle has three sessions, each of which contains application of making net work of a topic to make sentences. The term of method a self reflective spiral of cycle contains of planning, action, observation, and reflection (Figure 1). 
This investigation made use of a member of pre- test, post-test and research design. This classroom action study focused on the effectiveness of the error analysis strategy to improve the student's knowledge and ability in writing correctly. The study was started by administering Initial Reflection (IR) to the subject whose purpose was to evaluate the existing knowledge of writing skill, belonged to the subject. The IR which was administered to the subjects consisted of ten sentences and short paragraph that were grammatically and lexically incorrect. For the sake of establishing the degree of the increasing of writing ability of the subjects can be seen in the following steps of action.

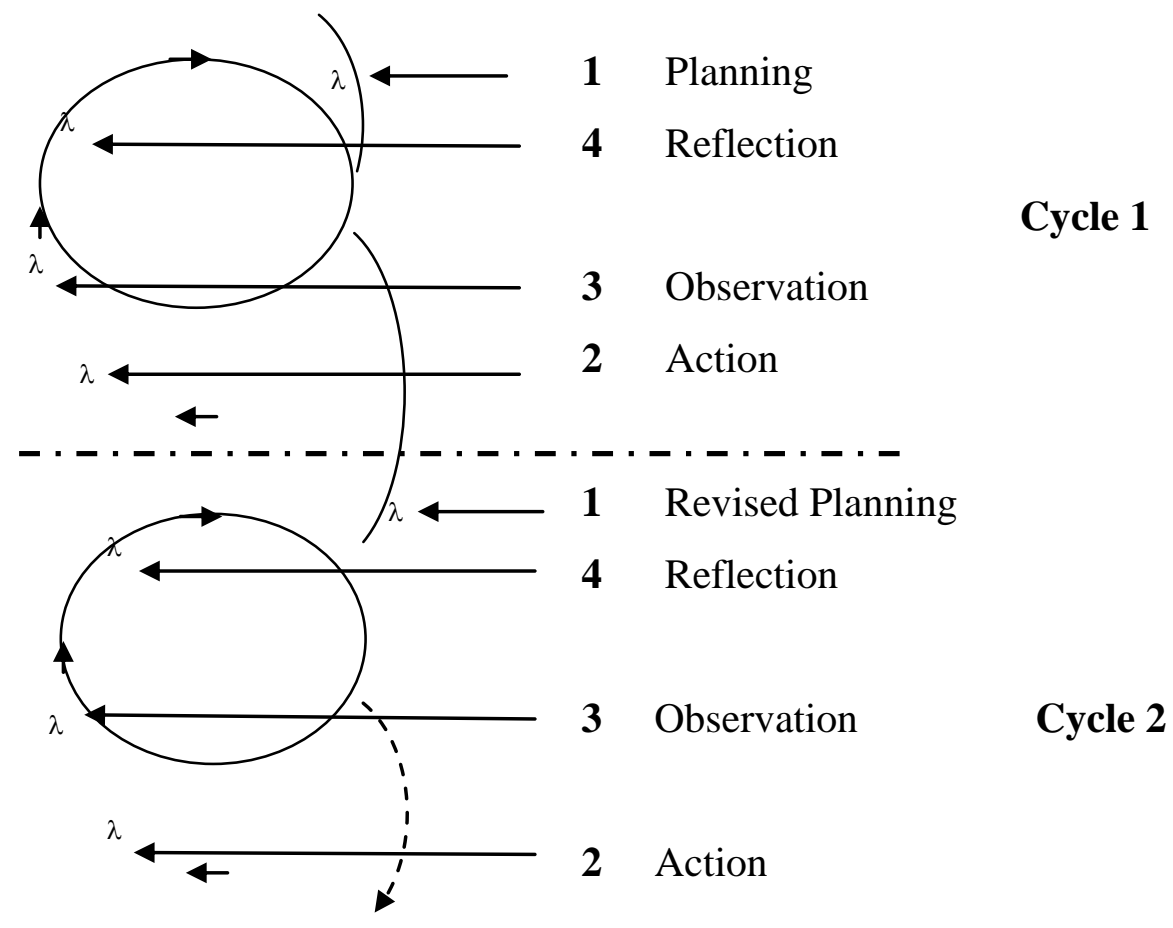

Figure 1. The major cycles and sessions of class action research

\section{Initial Reflection}

This primary step of action was conducted in order to recognize the pre-existing student's writing skill under study. The main score of the pre-test was very useful to get feedback to step forward next action.

\section{Planning}

In order the action study could be successfully done, the researcher had to make instructional planning for the whole sessions. The present study was substantially based on the fact that the subject under study still had low ability in English writing skill. Some plans were concluded by the researcher to gain instructional means activities as described below: 1) Determination of the subject under study 2) Application of IR was intended to measure the 
real pre-existing writing skill of the subject in English. 3) Design of teaching scenarios for present classroom with Conceptual Network 4) Construction of post-test at the end of each meeting. 5) Delivery of questionnaire to the students was finally intended to measure quantitatively the changing learning behaviors of the subject

\section{Actions}

The implementation of previously planned teaching scenarios was the main activity in this classroom action study. Plan has meaning if it is actualized through direct action through three phase activities.

\section{Observation}

The observation conducted by the researcher was intended to establish whether or not the teaching and learning process through Conceptual Network strategy in improving student's writing had been well. The researcher who acted as a teacher and an observer attracted the subject participation and involvement with writing activities. It was also meant to perceive, whether the subjects had any positive changing behaviors, motivation and attitudes on the part of the subjects.

\section{Reflection}

The term of reflection has the similar meaning with evaluation through post-tests activities which was done by the researcher during the action study. Because this study consisted of two cycles one of which had three meeting. The researcher conducted six times reflection. Each reflection was administered during the post- activities of each session. The subjects works were analyzed and corrected the student's analysis toward errors given in the sentences was corrected and scored criteria and percentage of the score is concisely discussed in following data analysis.

\section{Instrumentation}

Research instrument is entirely important in any research to measure the effectiveness of discovery process. There are three different tests used in this study namely; student's writing test, observation sheet, and questionnaire which are concisely displayed.

\section{Data Collection}

Data collection was taken through population and samples to which the action applied. The researcher selected the students of SMP Negeri 3 Kuta Selatan as the population and sample in academic year 2009-2010. There are two kinds of data collection gathered in study; quantitative and qualitative data. The quantitative data showed the finding of students' 
abilities in writing skill in the form of mean score taken from pre-test and post-test in each cycle while, the qualitative data was taken from the pre-test, post-tests, and questionnaire.

\section{Data Analysis}

The most valuable data required to answer the research under study was to collect data from pre-test, post-test and additional questionnaire data. The data is calculated through mean that consisted of the average score of student's achievement in writing test, the sum of total score is divided by the number of students' data analysis.

\section{FINDINGS AND DISCUSSION}

The findings of present study showed in all figures above, will be discussed to point out the degree of students' writing skill in terms of mark, scores, grand mean of both cycles and percentage of items in questionnaire indicating the changing behavior toward writing skill and strategy applied. The main of IR scores attained by students under study was 4,83 which was considered low according to description of rate in 20 scale. Due to realization of writing ability is very important, the quality, mastery and competency of aspects in speech must be improved by applying relevant writing classroom technique called Conceptual Network strategy which was conducted in cycle I and II to cover the difficulties faced by students in Pre- test.

The result of data analysis of reflection scores in cycle I, the scores increased significantly from lesson to lesson. The main score of R1 was 5.47 and then R2 was 6.09, further more; R3 was 6.83. The grand mean of cycle I was 6.13. In comparison with the main score of IR, the value increased 1.30 points which meant that students' writing ability through Conceptual Network strategy had been upgraded gradually.

Further more; the analysis of reflection score in cycle II drastically arose from every lesson. In R4, student's score in writing skill was 7.47. In R5 the main score was 8.21. Finally in R6, the main score was 8.76. The calculation of these scores into grand mean was 8.14. The grand mean of cycle II increased 2 points from cycle I and it upgraded 3.31 points from pre-test.

The responses of questionnaires that consisted of ten items indicated the subject's attitude and motivation in writing skill. The questionnaire of item A was responded by $59.25 \%$, item B was responded by $32.43 \%$, and item $\mathrm{C}$ was chosen by 8 . $31 \%$. From the respondents no students responded item $\mathrm{D}$. This means the indication of changing learning 
behaviors on students could influence students writing ability through positive motivation, and interest.

The findings of present classroom study indicated the effectiveness of Conceptual Network strategy in improving writing ability on IX 1 students of SMPN 2 Kuta Selatan The researcher fully realized that establishment of the findings was hard work and good cooperation of the subjects, teacher in charge, and the researcher.

\section{CONCLUSION}

Clearly the strategy had increased their qualitative out puts which can be recognized from gradually increasing score and qualitative outcomes that could be proved from their better ability in writing short paragraph grammatically appropriate. Rapid enrichment of their vocabularies was also improved. This upgrading score can be found in grand mean score of cycle I and cycle II. Some supplementary data which was collected from questionnaires could represent their clear insight of their changing behavior, motivation, interest when they write after improving their ability through Conceptual Network Strategy

The main score of pre-test or IR of tenth grade students in SMP Negeri 3 Kuta Selatan was only 4. 83. This rate means the ability of student's writing skill was considered very low It was recognized that the strategy worked effectively due to the results of post- test in every lesson of cycle I. From reflection to reflection the main score gradually improved. The main score of reflection 1 was 5.47, reflection 2 was 6.09 and reflection 3 reached to 6.83 . The grand mean of cycle I was 6.13. Comparing to the main score of pre-test, post test in cycle I was significantly upgraded 1.30 points from pre-test. From this fact, it was proved that the student's writing ability was considered fairly satisfactory by applying the strategy.

The findings of present classroom action study in class IX 1 SMP Negeri 3 Kuta Selatan convincingly revealed that the teaching through Conceptual Network strategy could effectively improve the student's achievement and factual ability in writing English appropriately.

\section{SUGGESTIONS}

Though English teachers of class IX 1 SMP Negeri 3 Kuta Sealatan are professionally dedicated and smart, they should be more creative, active and innovative in applying appropriate techniques to improve certain language skill, and the test given should be relevant with the skill being taught. Encouraging the students to improve their pre-existing ability in writing must be a priority for English teachers of class IX 1 SMP Negeri 3 Kuta Selatan The 
encouragement can positively influence their weak motivation, sense of being challenged by giving them more opportunity to write short paragraph about an interesting occasion. However little effort they make, the teachers should applause them as respectful rewards due to the difficulty of this productive skill.

\section{REFERENCES}

Alexander, LG.1994. Question and Answer. London: Longman Group Limited Ackley, E.1986. Macmillan English. New York: Collier Macmillan Canada Inc.

Brumfit,C.J. and Johnson.K. 1985. The communicative Approach to Language Teaching. Oxford University Press

Crass, D. 1991. A practical Handbook of language teaching. London: Cassel.

Harmer, J. 1998. How to teach English. England Addison Wesley Longman Limited.

Hornby, As. 1974. Oxford Advance Learners Dictionary of current English, third Edition, Oxford University Press.

Heaton, J.B. 1988. Writing English Language Test. London: Longman Group Ltd.

Hubbard, P. 1983. Teaching English as Foreign Language. London, Oxford University Press.

Kessler, C. 1992.Cooperative Language Learning. New Jersey: Prentice Hall

Kurikulum Sekolah Menengah Atas , 1995. Garis- Garis Besar Haluan Program Pengajaran (GBPP) Mata Pelajara Bahasa Inggris: I, II, II. Jakarta: Departemen Pendidikan dan Kebudayaan

Li Shing, T. 1981. English through Picture. English Teaching forum Vol. XII No 4.

Nunan, D. 1991. Language Teaching Methodology. New York: Practice Hall International.

Peaty, D. 1985. Functional Practice. East Bourne: Cassel Ltd.

Rivers, W.J.D 1968. Teaching Foreign Language Teaching Skill Chicago: The University of Chicago Press Practice. Menlo Park. California; Addison -Wesley Publishing Company. 